\title{
BRIDGING ECOLOGY AND ECONOMY THROUGH ISLAMIC ETHICS OF STEWARDSHIP
}

\author{
Erin Gayatri
}

\author{
Religion and Cross-Cultural Studies, Gadjah Mada University \\ Jl. Teknika Utara, Pogung, Yogyakarta, Indonesia, 55281, \\ Phone: +62-274-544976 \\ Correspondence E-mail: Erin.gayatri@mail.ugm.ac.id
}

Received: June 2017; Accepted: October 2017

\begin{abstract}
Even though it's originated from the same word oikos, literally means house, the discussion about ecological economics tend to be located in the opposite enterprises. In the abstract level, the discussions about ecology focus on the sustainability and conservation of biodiversity while the economic discourses lean toward the development and growth. Furthermore, many environmentalists accuse the thriving economic growth and development lead to ecological calamity. On the other hand, the economics technocrats suspiciously perceive the environmentalist as anti-growth and development. Even though Islamic classical literatures do not contain the word economy and ecology, yet the discourse about maintaining the limited resources of the earth for human development and growth have already and continuously scrutinized. Reflecting from the situations, this paper tries to bridge the tense relation between ecology and economy by elaborating the Islamic ethics of stewardship into both field studies. In doing so, the discussion shall begin by examining the field of ecology and economy in order to find common ground between the two. The ways we comprehend ecology in Islamic perspectives helps us to refine our understanding and practices in Islamic economics, and vice versa, this "green" Islamic economy might contribute to enhance our environmental situations.
\end{abstract}

Keywords: ecological economics, Islamic ethics, stewardship JEL Classification: Q57, Z12, Q50

Abstrak: Meskipun berasal dari kata yang sama oikos, secara harfiah berarti rumah, diskusi tentang ekonomi ekologi cenderung berada di perusahaan yang berlawanan. Pada tingkat abstrak, diskusi tentang ekologi berfokus pada keberlanjutan dan konservasi keanekaragaman hayati sementara wacana ekonomi mengarah pada pengembangan dan pertumbuhan. Selanjutnya, banyak pemerhati lingkungan mengklaim bahwa pertumbuhan ekonomi dan pembangunan menyebabkan bencana ekologis. Di sisi lain para teknokrat ekonomi curiga menganggap lingkungan sebagai anti pertumbuhan dan pembangunan. Meskipun literatur klasik Islam tidak mengandung kata ekonomi dan ekologi, namun wacana tentang pemeliharaan sumber daya manusia yang terbatas untuk pembangunan manusia dan pertumbuhannya telah dan terus diteliti. Bercermin dari situasi, makalah ini mencoba menjembatani hubungan yang bersitegang antara ekologi dan ekonomi dengan menguraikan etika etika penatalayanan ke dalam kedua studi lapangan. Dengan demikian, diskusi dimulai dengan memeriksa bidang ekologi dan ekonomi untuk menemukan kesamaan antara keduanya. Cara kita memahami ekologi dalam perspektif Islam membantu kita memperbaiki pemahaman dan praktik kita di ekonomi Islam, dan sebaliknya, ekonomi Islam "hijau" ini mungkin berkontribusi untuk meningkatkan situasi lingkungan kita.

Kata kunci: ekonomi ekologi, etika Islami, penatagunaan

Klasifikasi JEL: Q57, Z12, Q50 


\section{INTRODUCTION}

Long history of human being has undergone contamination one another which always changes their culture. In the midst of globalization, people attempt to maintenance their culture as identity from the other cultures. If the culture that we have today comes from long process of contamination with the other cultures, why human should be worried and attempt to avoid it? (Appiah 2016, p.24), whereas, the other crucial factor that affects human cultural change is nature. Moreover, religion is shaped by natural world such how the natural world forms the context of religious beliefs and practice (Bauman and O'Brien 2011, p.49). Consequently, there is a mutually influencing between nature and culture.

Ecology as a nature and economy as a culture are the part of human crisis. In term of ecology crisis, many scholars have demonstrated the climate change with many evidences such as, the rising level of the sea directly impacting Kiribati Island, the uncertain of weather impacting the plant times of the peasant which is determined whether successful harvest or not. While the economy crisis happened in some particular region and people such the slums area in the world, the other case about the refugees looked for better life like financial in the other place. Besides those conditions, ecology and economy tend to be located in the opposite enterprises.

The discourses about economy concern in the goals of development and growth, such as, how to complete the human needs and (wants) with the empowerment of natural resources. Hartman in Bauman and O'Brien (2011, p.147) argues that economics is an esoteric discipline understood by few experts. There has complexity in the process of supply, demand, production, distribution, and consumption of goods and service. However, people only do the economic activity without an adequate understanding. We could not deny that our economy today almost using economy capital where individual people is liberated to refine the meaning of possessing. There is no limitation for the people to collect their wealth. Even though the people have to regard the environmental problem. Indeed, there has power relation on building the market as the main place within economy activity. Time by time the market always lifts the human needs until we are in the midst of the ambiguity of basic needs today. The explosion of realm industries has brought the big impact to the ecological crisis. The air and water pollution, footprints of mining, biodiversity loss and calamity of ecological condition. According to Herman Daly as the founder of ecological economics, it reminds us that the human economy is embedded in and dependent on the natural ecosystem of our planet (Daly in Coward and C. Maguire 2000, p.31). Competing of market in the free trade demands the industry to extend their area empowering natural resources. For instance, in the Centre of Sulawesi where some of green village was changed to industrial places recently.

Ecology as the big idea about relation between human and non-human being like the chain which connect at all. Ecology understood by Haeckel is both natural and world view (Haeckel in Bauman and O'Brien 2011, p.49). Environmentalists have argued that what we have done already arrant. We have to doubt the modernity as the "pride period", modernity was perceived as the progress of human life where the people are easily to get what they want and when they want to go. Global economy operated in the free market and welcoming investor from different nations bounded the economy international organization. Uncommonly, Bruno Latour is against our claim that we are modern people in the modern era better then past. For Latour, "we have never been modern" because today we are in the uncertainty and brutality action particularly to the human and nature (Latour in Blok and Jensen 2011, pp.52-53). We have to redefine our understanding about modernity, it is not merely 
about the technology, science, economy and political progress. More than those, we have left the substantial understanding of modernity whereas the human is our responsibility to keep the balancing.

Ecology and Economy from the same root is oikos which means home, economics is the study of how humans manage household and system, and ecumenism is the effort to foster understanding and unity between different faith traditions, then in the broad meaning the scholar change the way we understand in which it is related to care about the world around us (Bauman 2011, p.147). Related to the explanation of the different interest way, between Ecology and Economy virtually have the same root, yet, why are both ultimately separated in the realities? It is inherently how the human develop or decline the genealogy of category in practice.

\section{RESEARCH METHOD}

This research is categorized as qualitative research conducted by inquiry the literatures on Islamic view and ethics about ecology and economy. Then, it looks for the way of Islamic ethics dealing with ecology and economy problems. This paper will examine to what extent is the Islamic ethics rule related to both issues.' Here the writer uses some theories which discuss the encounter between ecology and economy within Islamic ethics of stewardship.

\section{RESULT AND DISCUSSION}

\section{Gap between Ecology and Economy}

Inquiry the gap between ecology and economy in perceiving the human welfare is probably that we could begin in the simply case, how both terms response and define sustainability. Willis Jenkins explains three models of sustainability, first, economic model of sustainability, it is proposed to sustain welfare in the form of capital. Jenkins compare with the classical definition of Robert Solow, sustainability poses an investment problem in which societies must use returns from using natural resources in order to create new opportunities of equal or greater value. Here, the ideal and justice concepts are related the environment as the protection sphere. Second, the ecological model of sustainability proposes to sustain biological diversity and ecological integrity. Directly they focus on the health of the living world rather than welfare or capital. There are two points of view to decide which ecological goods can be sustained. From Anthropocentric point of view, the essential natural resources and the ecological system and regenerative processes in which human system relies should be sustained. Then, from economic point of view, species should be sustained for the intrinsic value. Thirdly, it is the political model of sustainability which proposes to sustain social system that realizes human dignity. This model focuses on sustaining the environmental condition of a fully human life (Jenskin in Bauman 2011, p.147).

Based on Jenskins' three models of sustainability, it is unequivocal to see that there are gaps among economic sustainability, ecological sustainability, and political sustainability. Indeed, the global economy also creates the global slums (Davis, 2006). There is an erroneous when the natural resources are used to the development of economy, yet, those could not decrease the poor and suffering people in effective changing. Moreover, the development of economy has made the nature suffer. In the other hand, ecological and political sustainability look for the balancing condition on how the human and nature live in the harmony.

\section{Islamic Ethics of Stewardship}

Two main resources of ecological crisis are modern science and modern economic system (Bagir and Martiam, 2016, p.80) where it refers to Western discovering and developing. Thereby, many scholars attempt to bridge those causes with ecological crisis in diversity views. 
Here, for the particular case of Islamic economy, this paper attempts to bridge the ecological crisis and Islamic economy with the concept of stewardship in Islamic ethics. Some scholars (Race, 1999; Haq, 2001; Jha, 2014) have written about the concept of khalifah, in some words such as stewardship, trusteeship, viceregency and the servant of God. Those words show that the main problem of ecological crisis is the actor of threat in this world, namely human. In daily life, human do their profession by using many world views and references and one of them is the reason of religious thought. With the concept of khalifah, human have to be back on the root if Islamic thought influences their duty in many spheres. Even though human always attempt to negotiate what they have to do in the midst of modernity, people merely bring the concept and principle in the idea not the real practice. It is like what Nasr said, today people desacralize the nature so people are difficult to reach the religious reason in the practice.

As the khalifah, man doubted to angels when the God mention that he will create the human. Mentioned by Qur'an that "And (mentioned) when the Lord said to the Angels", "indeed, I will make upon the earth a steward" the Qur'ân (Surah Al-Baqarah: verse 30), then the response of angels is that "They (the angels) said "will you place upon who it one causes corruption therein and shed blood, while we declare you the praises and sanctify you? God said: I know which you do not know. And he thought Adam the names- all of them".

Today we may say that we have done what angels said for long time, yet, we have not yet approved what God mentions about what does the meaning of God know which angle does not know? It may be the sign of the human that as long as they believe and feel closer to the God, they will approve that human did not like angel suspect. As the khalifah on the earth, the Qur'àn and Hadith mention anything what people have to do. Even though the other scholar said that it is merely defensive, if no apologetic, virtually I agree that it happened in some cases. However, we have to be aware what is the main problem of people particularly Muslims who only arrived in that position when we have paired with environmental issues? Otherwise the other case like being mentioned by the Qur'ân and Hadith in the way that do the people interpreting it to do terrorism really works? We will discuss it below.

\section{How Islam Response to Ecology}

Modern environmental problems have not only material but also moral and spiritual dimensions (Kamali, 2010, p.4), hence, we brought the scriptural sphere to face the environmental crisis. Qur'an contains of many sides of ecology, if the contradistinction to seeing nature as separation is possibly, it is instead of being permeated with the signs of God, essentially being the unfolding Creative Act of God Himself, then accordingly the maintenance of such harmonious balance becomes the imperative of faith based on stewardship.

Jha (2014) has presented some related verses which gave the depth meaning on how the contents of the Qur'ān reflect people on how God communicated to the human through the histories including the thought of ecological and economical maters.

"And the heavens He has lifted and placed the Balance; that you not exceed the Balance. So establish just measure and do not upset the Balance." [Qur'an 55:7-9]

As the command "do not upset the Balance "implies, Islam states that the intricate balance within nature is inherently disruptable, where the key responsibility (amānah) of stewardship (khiläfah) to maintain it arises. Islam sees nature as a cosmic book, the word "Ayāt" refers not only to Qur'anic verses, but to natural signs within the cosmos, implying that both have instructive qualities required to be reflected, deciphered and acted upon (Nasr in Jha, 2015, p.6). 
"Most surely in the creation of the heavens and the earth and the alternation of the night and the day, and the ships that run in the sea with that which profits men, and the water that God sends down from the clouds, then gives life with it to the earth after its death and spreads in it all animals, and the changing of the winds and the clouds made subservient between the heaven and the earth, there are "signs" (lit.Ayāt) for a people who understand." [Qur'an 2:164]

The story of Prophet Solomon became the main reflection that even the colony of ant, the communication of ants has inspired to pray to the God in gratitude:

"Till, when they came upon a valley of ants, an ant exclaimed: "O you ants! Get into your dwellings, lest Solomon and his soldiers crush you without being aware!" Thereupon (Solomon) smiled joyously at her words, and said: "O my Sustainer! Inspire me so that I may be grateful for those blessings of Yours with which You have graced me and my parents, and that I may do what is right that will please You; and include me, by Your mercy, among Your righteous servants!" [Qur'an 27:18-19]

Jha (2014) depicted in the beautiful sentences how the Quran represented God willing and means about the nature,

"Hence, the Qur'anic portrayal of nature is one of a repository for the glorification of God, a gift of sustenance, whose sacrosanctness demands attention and discernment to the messages. By way of further guidance, the Qur'ān itself is replete with the illustrative analogies of nature implying a deep interconnectedness with all that exist. From "fecundating winds" that carry pollen to produce blossoms are the indicative of God's divine mercy, to the oft-mentioned theme of rain giving life to barren land as illustrating God who brings dead hearts which are back to life; natural phenomena are consistently posited a source for revelatory communication, revealing both what is right and wrong, highlighting the deeper meaning behind the role of crisis."

\section{How Islam Talk about Economy}

The emergence of Islamic economy is to offer the new alternative way responding to the collapse of conventional economy (Aydin, 2013, 3). Even though Islamic economics overlaps with the conventional economics in terms of dealing with scarce resources in order to fulfil the needs and wants of human beings, it differs significantly in the way it answers to the core economic questions and defines human needs and well-being. While conventional economics emerging within the materialist worldview is solely based on human reason, Islamic economics is based on human reason and the divine guidance (Khan, 1989). The true scope of economics must be closely relevant to Islamic ethical systems, which arrange the way in which we live, the morality of all aspects of behaviour and its implications and the means, measures and ideal aspirations and goals of man in this world and hereafter. In this sense, there is a very legitimate basis for developing logical connections between Islam and study of human and ecological economics (Hassan 2005, p.16).

The principles of the Islamic economy in the light of the Qur'an and the sayings of the Prophet Mohammad are to improve the quality of the economy by encouraging good and forbidding the harmful. The main aims of the Islamic economic system are to increase justice, decrease extravagance, increase welfare, decrease exploitation, increase equality and fairness, and undermine discrimination (Hassan, 2015, p.23). Islamic economy well known as Islamic Sharia is the part of rules in Islamic way of life based on the Qur'an and hadith. One of the core concept of Islamic economy avoids usury for the other scholar as the simple and common ground, yet, in the extent understanding usury is very important to the subject matter of Islam and the environment (Dutton in Richard and Baharuddin, 2003, p. 331). Amidst realization that the current financial system is unsustainable precisely because it has been founded upon usury. It is increasingly becoming clear that there was no accidental purpose in nearly all the major world religions proscribing it. The definitive Qur'anic verse against usury is: 
"Those who consume interest cannot stand except as one who stands being touched by a Devilish touch into insanity. That is because they say, "Trade is [just] like interest." But God has permitted trade and forbidden interest. So, whoever receives an admonition from his Lord and desists may have what is past, while his affair rests with God...God blights interest and gives growth to charity...O you who have believed, be mindful of God and give up what remains [due to you] of interest, if you be believers. And if you do not, then be informed of a war from God and His Messenger. But if you repent, you may keep your principal oppress not and you will not be oppressed." the Qur'ān (Surah Al-Baqarah: verse 275-279]

Usury or riba in extended analogy on how human take more from the nature exhausted the nature. Human is not the owner of all creatures prominently the nature, human as the khalifah put together with the other creatures then be responsible to keep the harmony among the nature.

Further, Jha (2014) adjusts the values of Islamic economics related to the ecology into the contemporary problem where it is rare to be encountered. He presented interestingly to the four dominant features of usury that have become especially manifest today, namely:

a) Scarcity ("touched by a Devilish Touch") -The 'Devilish touch' or that of being "threatened with poverty and urged to immorality" the Qur'ān Surah Al-Baqarah: verse 269] affirms the old Wall street saying that the "financial markets are driven by two powerful emotions-fear and greed." Fear and greed are also related to the market which always lift the people need. People concern on how to compete and reach the maximum economical life style. With the people wants, economical proses would not find the ideal concept of welfare.

b) Distortion of Trade ("God has permitted trade and forbidden usury") -The paradigm of fair trade is distorted when coupled with interest. Today's trade liberalisation and IMF/World Bank/WTO policies have created a world where the development country as the dominant and showed the monopoly of the natural resources even human resources. Many countries in the midst of corporation did not get the equal result of economy. It is more to support the capitalism in the free trade rather than support the third world or the weakness economical state.

c) Ecological destruction ("be informed of a war from God") - Islam equates the practice of usury to a 'War against God'; interestingly this is the only such instance in the Qur'an of the use of such terminology.

d) Structural Oppression ("oppress not and you will not be oppressed") - structurally redistribute of the wealth from the wealth from the larger majority country to the small minority country.

The other main thought of Islamic economy is how God forbids extravagance and waste, in the Qur'an it is same as the devil brethren the Qur'ān Surah Al-Isra': verse 26). All of the creatures have their own proportion and measurement. One thing that is the most important is Islam talks about ecology and economy rapidly in many ayahs. Nevertheless, we could not deny that practically many kinds of "Islam" have different ways to interpret and apply it.

The influence of Islamic ethics particularly in the economical way to the environmental crisis is still doubted. After many of scholars contribute to propose and introduce the concept and principle of Islam, probably we should ask why it is not effective enough to change the people/Muslims interests, life style and the other kind of activities. We could see in the economical case, Islamic economy merely use the principle and basic Islamic ethics concept, yet, adapt the common economical operation. Because if we refer to the root, Islamic economy encouraged to lift quality economy of the poor 
and keep the balancing of environment as the natural resources. We even did not find the concept in the real operation, such as, how to apply the Muslims economical style. Islamic economy also did not take the clear position about the ambiguity of the human needs today. Even, Islamic banking also provides the unlimited wealth. While the poor people always increase every time along with the environmental crisis, it is related to Islamic ethics of stewardship in which people have to take the role in many spheres to secure the economy and ecological crisis. People could do it rapidly before it is too late. Our problem today is that it is difficult to against what we have done for long time. For instances, in the case of ecological crisis, we would find the limited article from the economists about how the economy activity bankrupts the earth now days. People who active discuss about it are dominant from the other science discipline. When the economists do that and attempt to apply it, it means that they have to do the big changes of economy activity.

\section{CONCLUSION}

After discussing the ecology and economy in Islamic world view, we could learn from both sides. How the environmentalists learn the Islamic economy concept that we could secure our environmental crisis without accusing the economic activity and how the economists learn the Islamic environment concept which passes the process of fulfilling the people needs (basic need not the developing need). We do not have to damage the nature. By using the key concept of khalifah, forbidding the usury, building the simplicity life and the other Islamic ethics, we have to refine the understanding and practice in Islamic economic. Islamic green economy is the result of dealing process among the main though in scripture (the Qur'an) about the ethics to decrease the poor people and keep the nature where both are as the creatures of God. There are the ethics which could not deny the reason of development. Thereby, we find the Islamic economy in the different face, Islamic green economy may contribute to enhance our environmental situations.

\section{ACKNOWLEDGEMENT}

Thank you for LPDP/Lembaga Pengelola Dana Pendidikan (Indonesia Endowment Fund for Education) which has been funded my master degree in Religion and Cross-Cultural Studies in Gadjah Mada University and also sponsored this paper.

\section{REFERENCES}

Akhtar, M. R. (1996). Towards an Islamic Approach for Environmental Balance. Islamic Economic Studies, 3(2), 57-77.

Appiah, K. A. (2006). The case for contamination. New York Times Magazine, 1, 32.

Aydin, N. (2013). Redefining Islamic economics as a new economic paradigm. Islamic Economic Studies, 21(1), 1-34.

Bauman, W. A., \& Bohannon, R. (Eds.). (2017). Grounding religion: A field guide to the study of religion and ecology. Taylor \& Francis.

Blok, A., \& Jensen, T. E. (2011). Bruno Latour: Hybrid thoughts in a hybrid world. Routledge.

Brown, J. H. (2013). Metaphysical Dimensions of Muslim Environmental Consciousness. Tabah Essays Series, (3).

Chapra, M. U. (2009). Ethics and economics: An Islamic perspective. Islamic Economic Studies, 16(1), 2-18.

Coward, H., \& Maguire, D. C. (Eds.). (2000). Visions of a New Earth: Religious Perspectives on Population, Consumption, and Ecology. SUNY Press.

Davis, M. (2007). Planet of Slums (2006). London $\mathcal{E}$ New York: Verso Google Scholar. 
Foltz, R. C., Denny, F. M., \& Baharuddin, A. (2003). Islam and Ecology. A Bestowed Trust, 3.

Haq, S. N. (2001). Islam and ecology: Toward retrieval and reconstruction. Daedalus, 130(4), 141-177.

Hassan, A. B. U. L. (2005). Islamic economics and the environment: Material flow analysis in society-nature interrelationships. JKAU: Islamic Economics, 18, 15-31.

Jenkins, W. J., Tucker, M. E., \& Grim, J. (Eds.). (2016). Routledge handbook of religion and ecology. Routledge.

Jha, Yusuf. (2014). Islam, Justice In. Economic and Ecological Justice in Islam.

Kamali, M. H. (2012). Environmental Care in Islam: A Quranic Perspective. Islam and Civilisational Renewal (ICR), 3(2).

Khan, M. S., \& Mirakhor, A. (1989). The financial system and monetary policy in an Islamic economy. Journal of King Abdulaziz University: Islamic Economics, 1(1), 39-57.

Rice, G. (1999). Islamic ethics and the implications for business. Journal of business ethics, 18(4), 345-358. 